\title{
Analisis Profil Eritrosit Tikus Putih (Rattus norvegicus) Pasca Diet Vegetarian
}

\author{
Arwan Bin Laeto ${ }^{1}$, Rara Inggarsih ${ }^{1}$, Septi Purnamasari ${ }^{1}$, Masayu Farah Diba ${ }^{1}$, \\ Fahmil Ikhsan Taharu ${ }^{2 *}$ \\ 1 Universitas Sriwijaya, Indonesia \\ 2Universitas Muhammadiyah Buton, Indonesia \\ *Korespondensi: fahmilikhsanbiologi@gmail.com
}

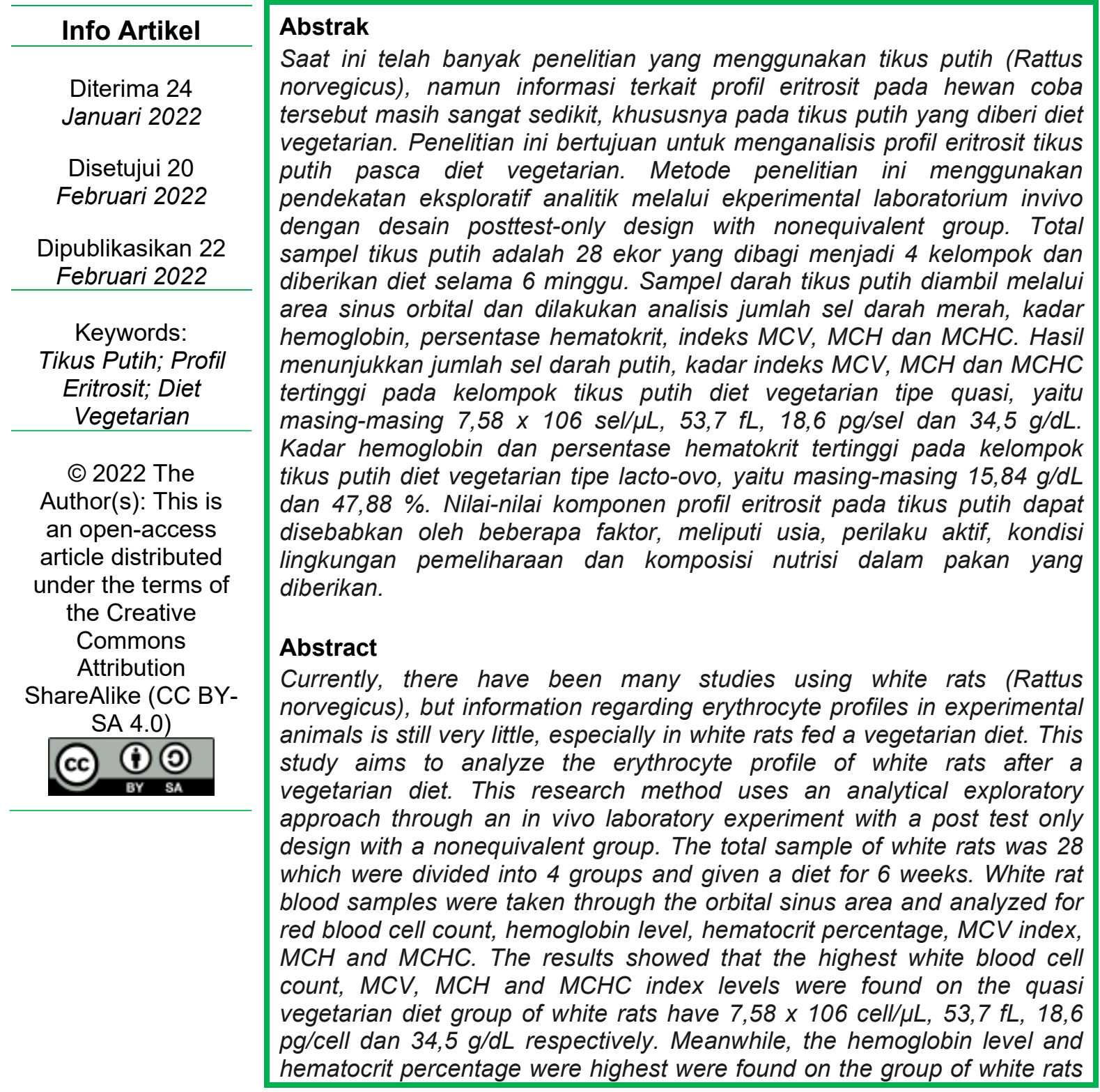


on a lacto-ovo vegetarian diet have $15,84 \mathrm{~g} / \mathrm{dL}$ dan $47,88 \%$ respectively. The values of erythrocyte profile components on white rats can be caused by several factors, including age, active behavioral, environmental conditions of maintenance and the nutrition composition in the feed given.

\section{Pendahuluan}

Tikus putih (Rattus norvegicus) yang merupakan salah satu hewan coba telah banyak digunakan dalam penelitian yang menerapkan metode eksperimen dan bersifat preklinis (Nugroho et al., 2018). Penggunaan hewan coba, seperti tikus putih, menjadi satu cara penting dan diperlukan di penelitian bidang biomedik, khususnya pada penelitian in vivo (Johnson, 2012). Keunggulan penggunaan tikus putih adalah hewan model ini memiliki database yang relevan dengan manusia sehingga mudah untuk melakukan interpretasi, siklus hidup tikus putih relatif pendek, biaya dan proses perawatannya lebih murah dan mudah (Said dan Abiola, 2014). Selain itu, tikus putih dapat dijadikan model untuk melihat gambaran penyakit manusia baik akut maupun kronis. Hal ini disebabkan kelengkapan organ, mekanisme biokimia dan metabolisme serta kebutuhan terhadap nutrisi tikus putih cukup mendekati manusia (He et al., 2017).

Tubuh yang sehat merupakan hal penting dalam mencapai kesejahteraan hidup. Kesehatan tubuh dapat dicapai melalui penerapan pola makan yang baik, seperti penerapan diet vegetarian. Diet ini menjadi trend saat ini karena mengedepankan pengaturan asupan makanan yang masuk ke dalam tubuh (Mariotti \& Christopher, 2019). Diet vegetarian juga diketahui mampu mencegah penyakit degeneratif, seperti hipertensi, stroke, kanker, diabetes mellitus dan gagal jantung. Diet yang tidak memasukkan komponen daging merah dalam menu makanan ini dapat menjadi faktor penurunan angka kematian akibat penyakit tidak menular (Duo, 2014).

Diet vegetarian merupakan pola makan dimana makanan yang dikonsumsi tidak bersumber dari semua daging merah, seperti daging sapi dan kambing. Berdasarkan tata gizi dan pola susunan menu makanan, diet ini dikategorikan menjadi tiga kelompok, yaitu diet vegetarian tipe quasi, lacto-ovo dan vegan (Mahan dan Escott, 2008). Diet vegetarian tipe quasi adalah diet yang dalam susunan menu makanan tidak terdapat sumber daging merah, namun terkadang masih mengonsumsi ikan dang unggas. Sedangkan tipe lacto-ovo vegetarian, susunan menu hanya mengonsumsi produk-produk hewani, seperti susu dan telur. Selanjutnya, pada diet vegan, yakni vegetarian ketat, susunan menu sama sekali tidak terdapat daging maupun produk hewani (Dagnelie and Mariotti, 2017). Ketiga tipe diet vegetarian ini dapat menjadi faktor yang dapat digunakan untuk mencegah penyakit tidak menular dan menentukan derajat kesehatan, yang mana dapat dianalisis melalui parameter biologis tubuh, seperti profil eritrosit (Pawlak, 2017).

Penelitian profil eritrosit yang dilakukan melalui analisis hematologi pada hewan sangat penting dilakukan. Hal ini disebabkan fungsi normal komponen darah akan menentukan keseimbangan mekanisme dari sistem kardiovaskuler, yakni mendistribusikan nutrien dan gas-gas essensial yang dibutuhan oleh setiap sel dan jaringan dalam tubuh serta mengeliminasi sisa metabolisme ke luar tubuh (Andeollo et al., 2012). Profil eritrosit meliputi komponen jumlah eritrosit, hemoglobin, hematokrit, $\mathrm{MCV}, \mathrm{MCH}$ dan $\mathrm{MCHC}$. Eritrosit merupakan sel berbentuk 
bulat dan memiliki struktur khusus, yakni mengandung hemoglobin dan enzim karbonat anhidrase. Struktur ini menjadikan eritrosit memiliki fungsi transportasi dalam sistem kardiovaskuler, dimana hemoglobin yang dimiliki eritrosit berfungsi mengikat oksigen dari paru-paru ke sel-sel tubuh. Sedangkan enzim karbonat anhidrase berfungsi meningkatkan reaksi pembentukan asam karbonat dari gas karbon dioksida dan air. Akibat dari reaksi ini adalah terbentunya ion bikarbonat yang kemudian diangkut dari jaringan menuju paru-paru (Boone et al., 2013).

Nilai komponen dari profil eritrosit dapat memberi informasi status kesehatan yang penting. Hal ini disebabkan data profil eritrosit dapat digunakan untuk membantu dalam penetapan karakteristik dan derajat kesehatan, serta membantu dalam menilai dan menegakkan diagnosa penyakit (Ihedioha et al., 2004). Kisaran normal nilai parameter yang terdapat dalam profil eritrosit hewan tikus putih dapat bervariasi. Variasi nilai fisiologis dari profil eritrosit ini dapat disebabkan oleh beberapa faktor, diantaranya jenis kelamin, kondisi geografis dan tipe pakan yang dikonsumsi oleh hewan coba tikus putih (Delwatta et al., 2018).

Penelitian yang memperoleh nilai profil eritrosit pada hewan coba yang menggunakan diet standar dilakukan dalam beberapa penelitian uji praklinis dan klinis (Said dan Abiola, 2014). Namun, informasi profil eritrosit pada tikus putih dengan diet pakan vegetarian belum banyak ditemukan. Sehingga, profil eritrosit pada tikus putih (Rattus norvegicus) pasca diberikan diet vegetarian menjadi penting untuk dianalisis guna melengkapi segmen informasi terkait parameter hematologi hewan coba tikus putih (Rattus norvegicus).

\section{Metode Penelitian}

Penelitian menggunakan pendekatan ekploratif analitik eksperimental laboratorium secara in vivo dengan desain posttest-only design with nonequivalent groups (Hastjarto, 2019). Penelitian dilaksanakan pada bulan November hingga Desember 2021 di Laboratorium Hewan Fakultas Kedokteran Universitas Sriwijaya. Populasi penelitian adalah tikus putih (Rattus norvegicus) galur Sprague Dawley berjenis kelamin jantan, diperoleh dari bagian perhewanan Pusat IImu Hayati ITB Bandung, yang berumur 8-9 minggu dengan berat berkisar antara 180220 gram.

Besar sampel ditentukan dengan menggunakan rumus Federer, yakni masing-masing kelompok terdiri atas 7 ekor tikus putih. Jumlah kelompok tikus dalam penelitian ditentukan berdasarkan tipe diet vegetarian, yang terdiri atas empat kelompk, yaitu quasi vegetarian, lacto-ovo vegetarian, vegan dan kelompok diet standar (Tabel 1). Sehingga total sampel penelitian yang digunakan adalah 28 ekor tikus putih. Sebelum digunakan untuk penelitian, semua sampel diaklimatisasi terlebih dahulu dengan menempatkan hewan coba ke dalam kandang bersih yang berukuran panjang $40 \mathrm{~cm} \times$ lebar $20 \mathrm{ccm} \times$ tinggi $10 \mathrm{~cm}$, suhu ruang $22-26^{\circ} \mathrm{C}$, kelembaban $60-70 \%$, diberi makan berupa pellet standar sebanyak $15-20$ gram/ekor/hari (10\% bobot badan tikus putih) dan minum secara ad libitum, serta pencahayaan diatur 12 jam gelap dan 12 jam terang.

Tabel 1. Komposisi Bahan Pakan Tikus Putih Tiga Tipe Diet Vegetarian

\begin{tabular}{cccc}
\hline \multirow{2}{*}{$\begin{array}{c}\text { Komposisi Bahan } \\
\text { (gram/1 kg pakan) }\end{array}$} & \multicolumn{3}{c}{ Tipe Diet Vegetarian } \\
\cline { 2 - 4 } & Quasi (gr) & $\begin{array}{c}\text { Lacto-ovo } \\
(\mathrm{gr})\end{array}$ & Vegan $(\mathrm{gr})$ \\
\hline Tepung Beras & 560 & 560 & 560 \\
\hline
\end{tabular}




\begin{tabular}{cccc}
\hline Tepung Ikan & 230 & 0 & 0 \\
\hline Susu Bubuk & 0 & 230 & 0 \\
\hline Tepung Kedelai & 0 & 0 & 230 \\
\hline Alpukat & 70 & 70 & 70 \\
\hline Buncis & 50 & 50 & 50 \\
\hline Bayam Hijau & 50 & 50 & 50 \\
\hline Sawi & 10 & 10 & 10 \\
\hline Kubis & 10 & 10 & 10 \\
\hline Bayam Merah & 10 & 10 & 10 \\
\hline Rumput Laut & 10 & 10 & 10 \\
\hline
\end{tabular}

Pada tahapan pembuatan pakan vegetarian, seluruh bahan makanan tikus putih dibersihkan, dipotong-potong dan dihaluskan lalu dicampurkan ke dalam bahan tepung hingga berbentuk ransum (Alimuddin et al., 2019). Hasil racikan ransum ini kemudian dimasukkan ke dalam mesin pelleting dan pellet selanjutnya dikeringkan dengan menggunakan oven dengan suhu $60^{\circ} \mathrm{C}$ hingga kering (Setyawati et al., 2017). Berikutnya, pelet vegetarian dilakukan repelleting bersama pakan standar. Proses ini penting dalam menerapkan teknik tappering untuk pemberian pakan pada tikus putih selama penelitian. Pada repelleting ini, $25 \%$ pakan vegetarian yang telah dihaluskan dicampurkan ke dalam $75 \%$ pakan standar dan diaduk hingga homogen (Taper et al., 1995). Selanjutnya, campuran tersebut dibuat menjadi ransum dan siap digiling kembali hingga menjadi pelet yang siap diberikan pada tikus putih (Masud dan Parakkasi, 2009).

Selanjutnya, pada tahap pemberian diet vegetarian, sampel terlebih dahulu ditimbang berat badan masing-masing tikus putih pada setiap kelompok dengan menggunakan timbangan digital. Berikutnya, pemberian pakan vegetarian dilakukan secara bertahap, yaitu sebanyak 20 gram/ekor/hari pada ketiga tipe diet vegetarian (Tabel 2). Pada setiap minggu, sebelum pakan diberikan, dilakukan kembali penimbangan berat bada tikus putih. Selain itu, jumlah pakan yang diberikan ditambah $20 \%$ setiap minggu sebagai antisipasi pertumbuhan tikus putih (Upa et al., 2017).

Tabel 2. Teknik Pemberian Diet Pada Tikus Putih Selama 6 Minggu Penelitian

\begin{tabular}{ccc}
\hline Minggu Ke- & Diet Normal & Diet Vegetarian \\
\hline 1 & $100 \%$ & $0 \%$ \\
\hline 2 & $75 \%$ & $25 \%$ \\
\hline 3 & $50 \%$ & $50 \%$ \\
\hline 5 & $25 \%$ & $75 \%$ \\
\hline 6 & $0 \%$ & $100 \%$ \\
\hline
\end{tabular}

Pada proses pengambilan sampel darah, tikus putih terlebih dahulu diposisikan dalam keadaan nyaman dan tidak stres. Sampel darah dilakukan melalui sinus retro-orbitalis dengan menggunakan alat tabung kapiler hematokrit. Darah yang mengalir melalui tabung kapiler tersebut kemudian ditampung ke dalam tabung eppendorf $1,5 \mathrm{ml}$ yang berisi anti kuogulan. Volume darah yang diambil pada masing-masing tikus putih adalah sebanyak $1 \mathrm{ml}$. Kemudian, darah yang telah ditampung dalam tabung eppendorf digoyang secara perlahan dan secara cepat dimasukkan ke dalam ice box. Pengukuran kadar profil eritrosit di laboratorium dilakukan dengan menggunakan alat hematology analyzer merek 
Sysmax XS-1000i. Komponen profil eritrosit yang diukur meliputi jumlah eritrosit, kadar hemoglobin, hematokrit, $\mathrm{MCV}, \mathrm{MCH}$ dan $\mathrm{MCHC}$.

Data numerik masing-masing komponen profil eritrosit yang diperoleh dianalisis secara univariat deskriptif numerik dengan menampilkan nilai rerata dan standar baku (s.b.) menggunakan aplikasi SPSS 24.0. Seluruh proses penelitian telah mendapat izin kelayakan etik dengan nomor sertifikat layak penelitian, yaitu No. Protokol: 125-2021 yang diterbitkan oleh Komite Etik Penelitian Kedokteran dan Kesehatan (KEPKK) Fakultas Kedokteran Universitas Sriwijaya.

\section{Hasil}

Penelitian ini dilakukan selama enam minggu, mulai dari tahapan aklimatisasi hingga analisis sampel darah tikus putih. Setiap minggu, bobot tubuh tikus putih ditimbang, baik pada kelompok tikus yang diberi diet vegetarian maupun kelompok kontrol yang diberi diet standar. Selama pemberian diet tersebut, terjadi perubahan bobot tubuh pada masing-masing tikus putih. Pada minggu pertama, berat tikus rata-rata adalah 203,5 gram (kelompok quasi), 229,3 gram (lacto-ovo), 218,8 gram (vegan) dan 214,3 gram (kelompok diet standar). Pada minggu kedua, terjadi peningkatan bobot tikus yang besar, terutama pada kelompok tikus putih diet vegetarian tipe lacto-ovo, yaitu meningkat menjadi 242,8 gram. Sedangkan kelompok tikus lain juga mengalami peningkatan, yaitu kelompok quasi menjadi 216,3 gram, kelompok vegan menjadi 230,3 gram dan kelompok diet standar menjadi 220,3 gram. Selanjutnya, pada minggu ketiga, kelompok tikus putih diet vegetarian tipe quasi mengalami peningkatan yang lebih tinggi dibandingkan kelompok lain, yaitu menjadi 227,8 gram. Sedangkan kelompok tikus diet tipe lacto-ovo, peningkatan bobot tubuh tikus menjadi 250,3 gram, diet tipe vegan 236,7 gram dan diet standar menjadi 230,8 gram. Pada minggu keempat, bobot tubuh tikus putih semua kelompok mengalami, yaitu menjadi 229,5 gram (diet quasi), 256,8 gram (lacto-ovo), 241,1 gram (vegan) dan 238,3 gram (diet standar). Berikutnya, pada minggu kelima, rata-rata bobot tikus putih kelompok diet vegetarian tipe quasi menjadi 232,2 gram, lacto-ovo menjadi 262, 7 gram, vegan menjadi 246,0 gram dan kelompok tikus putih diet standar menjadi 241,3 gram. Pada minggu terakhir, rata-rata bobot tubuh tikus putih mengalami peningkatan untuk semua kelompok, yaitu kelompok tikus putih diet quasi menjadi 236,7 gram, lakto-ovo menjadi 268,6 gram, vegan menjadi 255,5 gram dan kelompok tikus putih diet standar menjadi 245,5 gram.

Komponen profil eritrosit yang dianalisis melalui sampel darah tikus putih pada penelitian ini meliputi jumlah sel darah merah (eritrosit), kadar hemoglobin, hematokrit, $\mathrm{MCV}, \mathrm{MCH}$ dan $\mathrm{MCHC}$. Berdasarkan hasil analisis, ditemukan bahwa rerata jumlah dan kadar masing-masing komponen profil eritrosit berbeda pada antara kelompok tikus putih yang diberi diet vegetarian dengan tikus putih yang diberi diet standar.

\subsection{Rerata jumlah sel darah merah, kadar hemoglobin dan persentase hematokrit tikus putih berdasarkan kelompok diet}

Pada tikus putih (Rattus norvegicus), nilai normal jumlah sel darah merah adalh berkisar antara 7,30 - 9,68 (106 sel/ $\mu \mathrm{L})$. Jumlah sel darah merah dalam tubuh dapat mengalami perubahan oleh beberapa faktor, salah satunya dalah komposisi nutrisi dalam diet makanan yang dikonsumsi. Selanjutnya, kadar hemoglobin dalam darah pada tikus putih dapat dipengaruhi oleh banyak faktor, 
seperti umur, lingkungan tempat tinggal dan makanan. Normalnya, pada tikus putih kadar hemoglobin dapat berkisar antara 13,5-17,4 g/dL. Berikutnya, pada tikus putih, persentase normal hematokrit berkisar antara 40,5-52,0\%. Persentase hematokrit pada tikus putih sangat dipengaruhi oleh umur, makanan dan kondisi kesehatan tubuh. Ketiga komponen profil eritrosit ini memiliki peran sebagai pembawa oksigen dan nutrisi ke seluruh tubuh. Setelah pemberian pakan sebanyak 20 gram/ekor/hari, pada masing-masing diet, maka diperoleh rerata jumlah sel darah merah, kadar hemoglobin dan persentase hematokrit tikus putih (Rattus norvegicus) pada semua kelompok tikus putih dalam penelitian ini yang dapat dilihat pada Tabel 3.

Tabel 3. Rerata Jumlah Sel Darah Merah, Kadar Hemoglobin dan Persentase Hematokrit Tikus Putih

\begin{tabular}{ccccc}
\hline & & \multicolumn{3}{c}{ Komponen Profil Eritrosit } \\
\cline { 3 - 5 } Tipe Diet Vegetarian & $\mathrm{n}$ & $\begin{array}{c}\text { Rerata } \pm \text { s.b. } \\
\text { Jumlah Sel } \\
\text { Darah Merah } \\
\left(\times 10^{6} \mathrm{sel} / \mu \mathrm{L}\right)\end{array}$ & $\begin{array}{c}\text { Rerata } \pm \text { s.b. } \\
\text { Kadar } \\
\text { Hemoglobin } \\
(\mathrm{g} / \mathrm{dL})\end{array}$ & $\begin{array}{c}\text { Rerata } \pm \text { s.b. } \\
\text { Persentase } \\
\text { Hematokrit }(\%)\end{array}$ \\
\hline Quasi & 7 & $7,58 \pm 0,19$ & $15,72 \pm 0,15$ & $47,75 \pm 0,18$ \\
\hline Lacto-ovo & 7 & $7,56 \pm 0,20$ & $15,84 \pm 0,21$ & $47,88 \pm 0,13$ \\
\hline Vegan & 7 & $7,51 \pm 0,17$ & $15,67 \pm 0,16$ & $47,65 \pm 0,22$ \\
\hline Standar & 7 & $7,55 \pm 0,20$ & $15,59 \pm 0,19$ & $47,62 \pm 0,17$ \\
\hline
\end{tabular}

Sumber: diolah dari hasil penelitian (2021)

Berdasarkan Tabel 3 tersebut, rerata jumlah sel darah merah lebih tinggi pada kelompok tikus putih yang diberi diet vegetarian tipe quasi dibandingkan dengan dua tipe lainnya. Sedangkan rerata jumlah sel darah merah pada kelompok tikus putih yang diberi diet standar masih lebih tinggi dibandingkan kelompok diet vegetarian tipe vegan, namun masih dalam rentang nilai normal. Selain itu, pada tabel di atas juga terlihat bahwa rerata kadar hemoglobin pada kelompok tikus putih yang diberi diet vegetarian tipe lacto-ovo lebih tinggi dibandingkan kelompok lainnya. Berdasarkan hasil tersebut juga memperlihatkan bahwa pada kelompok tikus putih yang menjadi kontrol mencatat kadar hemoglobin paling rendah meski kadarnya masih dalam rentang nilai normal. Selanjutnya, hasil penelitian juga menunjukkan bahwa rerata persentase hematokrit paling tinggi terdapat pada kelompok tikus putih yang diberi diet vegetarian tipe lacto-ovo. Sedangkan kelompok dengan diet standar pada penelitian ini memiliki persentase hematokrit yang paling rendah. Namun, keempat kelompok yang diberi diet yang berbeda masih memiliki persentase hematorkit dalam batas rentang nilai normal.

\subsection{Rerata kadar MCV, MHC dan MCHC tikus putih berdasarkan kelompok diet}

Pada hewan coba seperti tikus putih, rentang normal kadar MCV adalah berkisar antara 48,9-57,9 fL. Nilai MCV darah dalam tubuh dapat dipengaruhi oleh makanan yang dikonsumsi. Selanjutnya, kadar $\mathrm{MCH}$ normal pada tikus putih adalah berkisar antara 17,1 - 20,4. Selain itu, pada tikus putih juga nilai normal kadar MCHC adalah berkisar antara 32,9 hingga 37,5 g/dL. Kadar MCV, MCH dan $\mathrm{MCHC}$ pada tikus putih dapat dipengaruhi oleh banyak faktor, salah satunya adalah jenis diet yang diterapkan dalam pola makan. Pada penelitian ini, setelah pemberian pakan sebanyak 20 gram/ekor/hari, pada masing-masing diet, maka 
diperoleh rerata kadar $\mathrm{MCV}, \mathrm{MCH}$ dan $\mathrm{MCHC}$ tikus putih berdasarkan jenis diet yang diberikan dapat dilihat pada Tabel 4 berikut.

Tabel 4. Rerata Kadar MCV, MHC dan MCHC Tikus Putih Berdasarkan Tipe Diet

\begin{tabular}{ccccc}
\hline \multirow{2}{*}{$\begin{array}{c}\text { Tipe Diet } \\
\text { Vegetarian }\end{array}$} & $\mathrm{n}$ & $\begin{array}{c}\text { Rerata } \pm \text { s.b. } \\
\text { Kadar MCV (fL) }\end{array}$ & $\begin{array}{c}\text { Rerata } \pm \text { s.b. } \\
\text { Kadar MCH } \\
(\mathrm{pg} / \mathrm{sel})\end{array}$ & $\begin{array}{c}\text { Rerata } \pm \text { s.b. } \\
\text { Kadar MCHC } \\
(\mathrm{g} / \mathrm{dL})\end{array}$ \\
\hline Quasi & 7 & $53,7 \pm 0,1$ & $18,6 \pm 0,11$ & $34,5 \pm 0,22$ \\
\hline Lacto-ovo & 7 & $53,5 \pm 0,2$ & $18,5 \pm 0,16$ & $34,1 \pm 0,19$ \\
\hline Vegan & 7 & $53,0 \pm 0,4$ & $18,3 \pm 0,12$ & $34,3 \pm 0,19$ \\
\hline Standar & 7 & $53,6 \pm 0,2$ & $18,5 \pm 0,14$ & $34,5 \pm 0,11$ \\
\hline
\end{tabular}

Sumber: diolah dari hasil penelitian (2021)

Berdasarkan Tabel 4 di atas, rerata kadar MCV pada kelompok tikus putih yang diberi diet vegetarian tipe quasi lebih tinggi dibandingkan dengan dua tipe lainnya. Sedangkan rerata kadar MCV pada kelompok tikus putih yang diberi diet standar juga lebih tinggi dibandingkan kelompok diet vegetarian tipe lacto-ovo dan vegan. Selain itu, kadar MCV tikus putih pada semua kelompok diet berada dalam rentang nilai normal. Selanjutnya, tabel di atas juga menunjukkan bahwa rerata kadar $\mathrm{MCH}$ pada kelompok tikus putih yang diberi diet vegetarian tipe quasi lebih tinggi dibandingkan kelompok diet vegetarian lainnya. Sedangkan kolompok tikus putih yang diberikan diet standar memiliki rerata kadar $\mathrm{MCH}$ yang sama dengan kelompok vegetarian tipe lacto-ovo. Berdasarkan hasil tersebut juga terlihat bahwa rerata kadar $\mathrm{MCH}$ pada semua kelompok tikus putih yang diberi diet pakan yang berbeda masih dalam rentang nilai normal. Pada penelitian ini juga diperoleh bahwa rerata kadar $\mathrm{MCHC}$ pada kelompok tikus putih yang diberi diet vegetarian tipe quasi lebih tinggi dari tipe lacto-ovo dan vegan. Pada tabel ini juga terlihat bahwa kadar MCHC pada kelompok tikus putih dengan diet standar sama dengan kadar $\mathrm{MCHC}$ yang terdapat pada kelompok tikus putih yang diberi diet vegetarian tipe quasi.

\section{Pembahasan}

Berdasarkan hasil penelitian, profil eritrosit tikus putih yang meliputi jumlah sel darah merah, kadar hemoglobin, hematokrit, $\mathrm{MCV}, \mathrm{MCH}$ dan $\mathrm{MCHC}$ menunjukkan nilai yang bervariasi. Hasil ini sejalan dengan penelitian sebelumnya yang menyatakan bahwa nilai komponen-komponen eritrosit sangat bersifat spesifik karena beberapa faktor, seperti lokasi pemeliharaan, iklim suatu wilayah saat dilakukan penelitian, keadaan geografi saat pemeliharaan dan jenis pakan yang diberikan pada tikus putih (Fitria \& Satrio, 2014). Jenis pakan yang diberikan pada tikus putih mempengaruhi konsentrasi dan jumlah nutrisi yang masuk ke dalam darah karena setiap jenis pakan yang diberikan memiliki komposisi yang berbeda antara satu dengan lainnya, sehingga nilai komponen profil eritrosit tidak dapat digenaralisasikan (Harsa, 2014; Rosidah et al., 2020).

Peningkatan bobot tubuh tikus putih selama penelitian terjadi akibat kandungan protein dalam pakan vegetarian dan pakan standar. Hal ini karena protein merupakan nutrisi yang berperan penting dalam menyusun protein struktural tubuh, sehingga terjadi pertumbuhan sel dan jaringan baru, yang berdampak pada peningkatan bobot tubuh hewan coba tikus puth (Leitzmann et al, 2014). Penerapan diet vegetarian, selain dapat menjadi alternatif sumber energi 
dan mencegah peningkatan kolesterol, substansi asam amino esensial dan non esensial yang membentuk protein dalam diet tersebut juga dapat berfungsi sebagai prekursor sintesis protein fungsional seperti enzim dan hormon. Hasil sintesis ini kemudian berperan dalam metabolisme pertumbuhan sel dan jaringan baru pada tikus putih (Wahyuni, Aryadi \& Firdaus, 2016).

Kelompok tikus putih yang diberikan diet vegetarian tipe vegan memiliki jumlah sel darah merah yang lebih rendah, namun masih dalam rentang normal. Sel darah ini berfungsi membawa oksigen dari paru-paru ke jaringan tubuh. Selain itu, sel darah merah juga memiliki peran dalam meningkatkan proses reaksi karbon dioksida dan air untuk membentuk asam karbonat dengan bantuan enzim karbonat anhidrase (Boone et al., 2016). Sel darah merah merupakan salah satu komponen darah yang memiliki struktur berupa hemoglobin. Struktur ini disusun oleh salah satu zat mineral penting dalam makanan, yaitu zat besi. Pada diet vegan, komposisi sumber protein sama sekali tidak diambil dari protein hewani, yang merupakan sumber utama zat mineral besi (Anggraini, Wiryatun \& Susetyowati, 2015). Selain itu, jumlah sel darah merah tikus putih (Rattus norvegicus) pada penelitian ini senada dengan penelitian sebelumnya yang menggunakan tikus putih, namun pada penelitian tersebut spesifik mengukur jumlah sel darah merah berdasarkan umur dan jenis kelamin (Rosidah, 2020).

Kelompok tikus putih yang diberikan diet vegetarian tipe lacto-ovo memiliki kadar hemoglobin yang paling tinggi. Hemoglobin dikenal sebagai kompleks protein-porfirin yang mengikat zat besi. Berat molekul hemoglobin mencapai 67.000 dalton yang tersusun dari empat kelompok heme dan masing-masing heme memiliki satu atom besi (Reece \& Rowe, 2017). Hemoglobin sebagai protein yang memiliki afinitas tinggi terhadap gas-gas respirasi berfungsi mendistribusikan oksigen yang diambil dari ventilasi paru-paru menuju sel dan jaringan tubuh yang membutuhkan untuk proses metabolisme energi (Thomas \& Lumb et al., 2012). Diet vegetarian tipe quasi dan lacto-ovo pada penelitian ini masih mengonsumsi protein hewani, seperti ikan dan produk-produk hewani seperti telur dan susu. Makanan yang memiliki sumber protein umunya membawa serta nutrisi lain, seperti zat besi dan vitamin B12. Keberadaan zat besi dan vitamin B12 menjadi penting dalam pembentukan hemoglobin karena rendahnya kadar hemoglobin dapat berdampak pada penurunan fungsi respirasi (Medawar et al., 2019).

Berdasarkan hasil penelitian ini, tikus putih yang diberikan diet, baik vegetarian maupun standar memiliki persentase hematokrit dalam rentang normal. Hal ini sejalan dengan penelitian sebelumnya yang melaporkan bahwa rentang nilai persentase hematokrit yang diperoleh pada tikus putih adalah $42,15 \%$ $48,30 \%$ (Rosidah, 2020). Hematokrit yang merupakan gambaran persentase sel darah merah per volume total darah terlihat lebih tinggi pada kelompok tikus putih yang diberi diet vegetarian tipe lacto-ovo. Diet tipe ini mengandalkan nutrisi protein dari produk-produk hewani seperti susu dan telur. Diketahui bahwa produk hewani seperti telur memiliki kandungan asam folat yang tinggi. Asam folat memiliki fungsi kimiawi sebagai kofaktor enzim dalam mekanisme reaksi metabolisme protein, seperti mekanisme pembentukan protein-protein hemoglobin (Saptyasih et at., 2016; Sari et al., 2019). Selain nutrisi, kadar hematokrit pada hewan coba juga dapat dipengaruhi oleh perilaku aktif tikus putih dan tingkat dehidrasi lingkungan tempat tikus putih dipelihara (Cora et al., 2012). 
Nilai MCV atau eritrosit rata-rata tikus putih pada penelitian ini relatif sama, yaitu berkisar pada indeks $53 \mathrm{fL}$. Nilai indeks eritrosit ini merupakan perbandingan jumlah hematokrit per jumlah eritrosit (Rosidah, 2020). Rerata MVC paling tinggi pada penelitian ini dicatat oleh kelompok tikus putih yang diberi diet vegetarian tipe quasi. Rerata MVC pada kelompok ini sama dengan kelompok tikus putih yang diberi diet standar. Pada kedua kelompok ini, dalam diet masih terdapat protein yang bersumber dari daging hewan. Nutrisi penting yang diperlukan dalam daging hewan untuk menjaga keseimbangan fungsi darah adalah zat besi dan vitamin B12 karena kedua nutrisi ini sedikit ditemukan dalam protein nabati (Pramartha, 2016). Zat besi berfungsi sebagai mineral penting penyusun hemoglobin yang kemudian menjaga keseimbangan persentase hematokrit dalam darah. Sedangkan vitamin B12 yang bekerjasama dengan folat berfungsi dalam proses sintesis sel darah merah, agar sel darah merah yang dibentuk memiliki ukuran yang ideal dan jumlah sel fungsional yang seimbang (Susianto, 2020).

Pada penelitian ini, rerata kadar indeks $\mathrm{MCH}$ tertinggi ditemukan pada kelompok tikus putih yang diberi diet vegetarian tipe quasi. Sedangkan rerata kadar $\mathrm{MCH}$ rendah dicatat oleh tikus putih kelompok diet vegetarian tipe vegan, namun masih dalam rentang normal. Indeks Mean Corpuscular Haemoglobin $(\mathrm{MCH})$ merupakan komponen profil eritrosit yang menggambarkan nilai berat hemoglobin rata-rata dalam sel eritrosit dan menunjukkan kemampuan eritrosit untuk mengantarkan oksigen dari rongga paru-paru menuju sel dan jaringan tubuh tikus putih yang membutuhkan (Rosidah, 2020). Diet vegetarian tipe quasi merupakan diet yang masih mengonsumsi protein sumber hewani seperti ikan, udang, dan unggas. Pada ikan, komposisi nutrisi anorganik dapat mencapai $2 \%$ dan salah satu mineral penting dalam nutrisi anorganik ini adalah zat besi. Kadar zat besi dalam daging ikan berkisar antara 0,5 - 3,5 mg. Selain berperan sebagai unsur kimia kofaktor fungsional enzim, zat besi juag berperan penting dalam pembentukan pigmen sel darah merah, yakni hemoglobin (Syahril et al., 2016). Sedangkan pada diet vegan, tidak ditemukan zat besi di dalam protein yang bersumber dari nabati. Sehingga hal ini akan berpengaruh pada kadar $\mathrm{MCH}$ dalam darah tikus putih (Obeid, 2002).

Kadar $\mathrm{MCHC}$ tikus putih yang diberi pakan diet vegetarian dan pakan standar berada pada rentang nilai normal. Namun ditemukan bahwa pada kelompok tikus putih yang diberi diet vegetarian tipe lacto-ovo memiliki kadar $\mathrm{MCHC}$ yang lebih rendah dibandingkan dengan kelompok tikus putih lainnya. Meski rendah, nilai ini masih dianggap kadar normal, yakni relatif sama dengan kadar MCHC pada penelitian sebelumnya yang hanya menggunakan pakan standar (Kartika et al., 2014). Nilai MCHC menggambarkan kadar hemoglobin rata-rata dalam satu sel eritrosit. Semakin tinggi nilai $\mathrm{MCHC}$ hewan coba, maka semakin efisien fungsi hemoglobin dalam mengikat dan mendistribusi gas-gas essensial bagi tubuh untuk menjalankan proses metabolisme energi dan respon tubuh lainnya (Sailes et al, 2013).

\section{Kesimpulan}

Berdasarkan hasil penelitian maka disimpulkan bahwa profil eritrosit yang terdiri atas jumlah sel darah merah, kadar hemoglobin, persentase hematokrit, kadar indeks MCV, MCH dan MCHC pada tikus putih (Rattus norvegicus) berbeda menurut tipe diet vegetarian dan diet standar. Nilai setiap komponen profil eritrosit pada semua kelompok masih dalam rentang nilai normal. Jumlah sel darah merah, 
kadar indeks $\mathrm{MCV}, \mathrm{MCH}$ dan $\mathrm{MCHC}$ pada kelompok tikus putih yang diberi diet vegetarian tipe quasi lebih tinggi dibandingkan kelompok tikus putih lainnya, yaitu rerata jumlah sel darah merah diet quasi adalah $7,56 \times 10^{6} \mathrm{sel} / \mu \mathrm{L}$, sedangkan pada diet lacto-ovo, vegan dan diet standar masing-masing adalah 7,56 $\times 10^{6}$ $\mathrm{sel} / \mu \mathrm{L}, 7,51 \times 10^{6} \mathrm{sel} / \mu \mathrm{L}$ dan $7,55 \times 10^{6} \mathrm{sel} / \mu \mathrm{L}$. Selanjutnya, rerata kadar indeks MCV diet quasi adalah 53,7 fL, sedangkan pada diet lacto-ovo, vegan dan diet standar masing-masing adalah 53,5 fL, 53,0 fL dan 53,6 fL. Rerata indeks $\mathrm{MCH}$ pada diet quasi adalah 18,6 pg/sel, sedangkan pada diet lacto-ovo, vegan dan diet standar masing-masing yaitu 18,5 pg/sel, $18,3 \mathrm{pg} / \mathrm{sel}$ dan 18,5 pg/sel. Berikutnya, rerata indeks $\mathrm{MCHC}$ pada diet quasi adalah $34,5 \mathrm{~g} / \mathrm{dL}$, sedangkan pada diet lactoovo, vegan dan standar masing-masing adalah $34,1 \mathrm{~g} / \mathrm{dL}, 34,3 \mathrm{~g} / \mathrm{dL}$ dan $34,5 \mathrm{~g} / \mathrm{dL}$. Kadar hemoglobin dan persentase hematokrit pada kelompok tikus putih yang diberi diet vegetarian tipe lacto-ovo lebih tinggi dibandingkan kelompok tikus putih lainnya. Rerata kadar hemoglobin pada kelompok tikus putih diet lacto-ovo adalah $15,84 \mathrm{~g} / \mathrm{dL}$, sedangkan kelompok diet quasi, vegan dan standar masing-masing adalah $15,72 \mathrm{~g} / \mathrm{dL}, 15,67 \mathrm{~g} / \mathrm{dL}$ dan $15,59 \mathrm{~g} / \mathrm{dL}$. Rerata persentase hematokrit pada kelompok tikus putih diet lacto-ovo adalah 47,88 \%, sedangkan kelompok diet quasi, vegan dan standar masing-masing yaitu 47,75 \%, 47,65\% dan 47,62\%.

Tikus putih (Rattus norvegicus) yang diberikan diet vegetarian dapat digunakan untuk menganalisis biomarker darah yang lain, sehingga penyakit dan gangguan kesehatan yang diderita oleh kelompok pelaku diet vegetarian dapat dianalisis secara komprehensif.

\section{Daftar Pustaka}

Alimuddin, A. et al. (2019) 'Behavior, histopathology and physiological responses of rat fed diets containing growth hormone transgenic fish meal', HAYATI Journal of Biosciences, 26(1), p. 1.

Andreollo, N. A. et al. (2012) 'Rat's age versus human's age: what is the relationship?', $A B C D$. Arquivos Brasileiros de Cirurgia Digestiva (São Paulo), 25, pp. 49-51.

Anggraini, L., Lestariana, W. and Susetyowati, S. (2015) 'Asupan gizi dan status gizi vegetarian pada komunitas vegetarian di Yogyakarta', Jurnal Gizi Klinik Indonesia, 11(4), pp. 143-149.

Azizah, D. I. (2019) 'Survei Asupan Zat Besi, Asam Folat, Dan Vitamin C Pada Remaja Putri Di Kecamatan Jatinangor'.

Boone, C. D. et al. (2013) 'Carbonic anhydrase: an efficient enzyme with possible global implications', International Journal of Chemical Engineering, 2013.Azizah, D. I. (2019) 'Survei Asupan Zat Besi, Asam Folat, Dan Vitamin C Pada Remaja Putri Di Kecamatan Jatinangor'.

Cora, M. C. et al. (2012) 'Artifactual changes in sprague-dawley rat hematologic parameters after storage of samples at $3 \mathrm{C}$ and $21 \mathrm{C}^{\prime}$, Journal of the American Association for Laboratory Animal Science, 51(5), pp. 616-621.

Dagnelie, P. C. \& Mariotti, F. (2017) 'Vegetarian diets: Definitions and pitfalls in interpreting literature on health effects of vegetarianism', in Vegetarian and plant-based diets in health and disease prevention. Elsevier, pp. 3-10. 
Delwatta, S. L. et al. (2018) 'Reference values for selected hematological, biochemical and physiological parameters of Sprague-Dawley rats at the Animal House, Faculty of Medicine, University of Colombo, Sri Lanka', Animal models and experimental medicine, 1(4), pp. 250-254.

Fitria, L. \& Sarto, M. (2014) 'Profil hematologi tikus (Rattus norvegicus Berkenhout, 1769) galur wistar jantan dan betina umur 4, 6, dan 8 minggu', Biogenesis: Jurnal Ilmiah Biologi, 2(2), pp. 94-100.

Harsa, I. M. S. (2014) 'Efek pemberian diet tinggi lemak terhadap profil lemak darah tikus putih (Rattus norvegicus)', Jurnal IImiah Kedokteran, 3(1), pp. 2128.

Hastjarjo, T. D. (2019) 'Rancangan eksperimen-kuasi', Buletin Psikologi, 27(2), pp. 187-203.Harsa, I. M. S. (2014) 'Efek pemberian diet tinggi lemak terhadap profil lemak darah tikus putih (Rattus norvegicus)', Jurnal IImiah Kedokteran, 3(1), pp. 21-28.

He, Q. et al. (2017) 'Sex-specific reference intervals of hematologic and biochemical analytes in Sprague-Dawley rats using the nonparametric rank percentile method', PloS one, 12(12), p. e0189837.

Ihedioha, J. I., Okafor, C. \& Ihedioha, T. E. (2004) 'The haematological profile of the Sprague-Dawley outbred albino rat in Nsukka, Nigeria', Animal Research International, 1(2), pp. 125-132.

Johnson, M. (2012) 'Laboratory mice and rats', Mater Methods, 2(10.13070).Ihedioha, J. I., Okafor, C. and Ihedioha, T. E. (2004) 'The haematological profile of the Sprague-Dawley outbred albino rat in Nsukka, Nigeria', Animal Research International, 1(2), pp. 125-132.

Leitzmann, C. (2014) 'Vegetarian nutrition: past, present, future', The American journal of clinical nutrition, 100(suppl_1), pp. 496S-502S.

$\mathrm{Li}, \mathrm{D}$. (2014) 'Effect of the vegetarian diet on non-communicable diseases', Journal of the Science of Food and Agriculture, 94(2), pp. 169-173.

Mahan, L. K. \& Escott-Stump, S. (2008) 'Krauses food, nutrition and diet therapy. ed'. Philadelphia: WB Saunders.Li, D. (2014) 'Effect of the vegetarian diet on non-communicable diseases', Journal of the Science of Food and Agriculture, 94(2), pp. 169-173.

Mariotti, F. \& Gardner, C. D. (2019) 'Dietary protein and amino acids in vegetarian diets-A review', Nutrients, 11(11), p. 2661.

Mas'ud, M. S. \& Parakkasi, A. (2009) 'Performa pertumbuhan tikus putih (Rattus norvegicus) yang diberi ransum berbagai taraf limbah udang', Jurnal Agripet, 9(2), pp. 21-27.

Medawar, E. et al. (2019) 'The effects of plant-based diets on the body and the brain: a systematic review', Translational psychiatry, 9(1), pp. 1-17.

Nugroho, S. W. et al. (2018) 'Profil Tekanan Darah Normal Tikus Putih (Rattus norvegicus) Galur Wistar dan Sprague-Dawley', Acta VETERINARIA Indonesiana, 6(2), pp. 32-37.

Obeid, R. et al. (2002) 'The impact of vegetarianism on some haematological parameters', European Journal of Haematology, 69(5-6), pp. 275-279. 
Pawlak, R. (2017) 'Vegetarian diets in the prevention and management of diabetes and its complications', Diabetes Spectrum, 30(2), pp. 82-88.

Pramartha, A. A. A. (2016) 'Perbedaan Kadar Hemoglobin pada Kelompok Wanita Vegetarian dengan Non Vegetarian', Intisari Sains Medis, 7(1), pp. 1-5.

Reece, W. O. \& Rowe, E. W. (2017) Functional anatomy and physiology of domestic animals. John Wiley \& Sons.

Rosidah, I. et al. (2020) 'Profil Hematologi Tikus (Rattus Norvegicus) Galur Sprague-Dawley Jantan Umur 7 Dan 10 Minggu', Jurnal Bioteknologi \& Biosains Indonesia (JBBI), 7(1), pp. 136-145.

Said, N. M. \& Abiola, O. (2014) 'Haematological profile shows that inbred Sprague Dawley rats have exceptional promise for use in biomedical and pharmacological studies', Asian journal of biomedical and pharmaceutical sciences, 4(37), p. 33.

Sailesh, K. S. et al. (no date) 'An Observation into Random Blood Glucose, Autonomic, Respiratory and Hematological Parameters in Vegetarians and Non-Vegetarians of Karukutty Village, Kerala State'.

Septyasih, A. R. N., Widajanti, L. \& Nugraheni, S. A. (2016) 'Hubungan asupan zat besi, asam folat, vitamin B12 dan vitamin C dengan kadar hemoglobin siswa di SMP Negeri 2 Tawangharjo Kabupaten Grobogan', Jurnal Kesehatan Masyarakat (Undip), 4(4), pp. 521-528.

Setyawati, I., Putra, I. \& Roni, N. G. K. (2017) 'Liver activity of rat (Rattus sp.) that given calliandra (Calliandra calothyrsus) leaf meal and pineapple (Ananas comosus) peel in the diets during the growth period.', Jurnal Biologi Udayana, 21(1), pp. 30-34.

Susianto, S. (2020) 'Efek Fortifikasi Vitamin B12 Terhadap Kadar Vitamin B12 Serum Dan Homosistein Serum Pada Vegetarian', Jurnal IImu Kesehatan Bhakti Husada: Health Sciences Journal, 11(1), pp. 114-120.

Syahrir, S., Soekendarsi, E. \& Hasyim, Z. (2017) 'Perbandingan kandungan zat gizi ikan mujair Oreochormis mossambica Danau Universitas Hasanuddin Makasasar dan Ikan Danau Mawang Gowa', BIOMA: Jurnal Biologi Makassar, 1(1).

Taper, H. S. et al. (1995) 'Protective effect of dietary fructo-oligosaccharide in young rats against exocrine pancreas atrophy induced by high fructose and partial copper deficiency', Food and chemical toxicology, 33(8), pp. 631-639.

Thomas, C. \& Lumb, A. B. (2012) 'Physiology of haemoglobin', Continuing Education in Anaesthesia, Critical Care \& Pain, 12(5), pp. 251-256.

Upa, F. T., Saroyo, S. \& Katili, D. Y. (2017) 'Komposisi pakan tikus ekor putih (Maxomys hellwandii) di kandang', Jurnal IImiah Sains, 17(1), pp. 712.Thomas, C. and Lumb, A. B. (2012) 'Physiology of haemoglobin', Continuing Education in Anaesthesia, Critical Care \& Pain, 12(5), pp. 251256.

Wahyuni, A. R., Arsyad, A. \& Hamid, F. (2016) 'Pengaruh Latihan Fisik Aerobik dan Anaerobik Terhadap Komponen Darah Perifer Pada Mencit Jantan', Jurnal Kesehatan, 6(4), pp. 388-392. 